\title{
PHARMACOLOGICAL INVESTIGATIONS OF LITSEA LANCIFOLIA (ROXB.) HOOK. F.
}

\author{
Israt Jahan Bulbul, Mohammad Rashedul Haque and \\ Mohammad Abdur RaShid*
}

\author{
Department of Pharmaceutical Chemistry, University of Dhaka, Dhaka-1000, Bangladesh
}

Key words: Litsea lancifolia, antioxidant, antimicrobial, analgesic, hypoglycemic, CNS depressant

\begin{abstract}
The petroleum ether, chloroform and ethyl acetate soluble fractions of methanolic extract of Litsea lancifolia Roxb. leaves were subjected to different pharmacological screenings to explore its potential as anti-oxidant, antimicrobial, peripheral analgesic, hypoglycemic and CNS depressing agent. The ethyl acetate soluble fraction showed highest total phenolic content and free radical scavenging activity compared to the standard, acetyl salicylic acid. Potential antimicrobial activity was shown against $P$. aeruginosa $(23.50 \mathrm{~mm})$, E. coli $(22.33 \mathrm{~mm})$, B. cereus $(18 \mathrm{~mm})$ and $S$. paratyphi $(18 \mathrm{~mm})$. The crude extract demonstrated significant peripheral analgesic $(\mathrm{p}<0.01)$ activity with 69.45 and $77.96 \%$ inhibition of acetic acid-induced writhing at 100 and $200 \mathrm{mg} / \mathrm{kg}$ b.w., respectively. The crude methanolic extract also showed significant hypoglycemic activity $(\mathrm{p}<0.01)$ at a dose of $500 \mathrm{mg} / \mathrm{kg} /$ day on the 7 th day of treatment. All the organic soluble fractions exhibited noteworthy $(\mathrm{p}<0.001)$ CNS depressant activity. Taken together, the plant can be considered as a good material for further chemical investigation to isolate the bioactive constituents.
\end{abstract}

Bangladesh is a great source of medicinal plants and for the purposes of traditional medication about 500 species are being used here (Yusuf et al. 1994). Plants remain as the novel source of structurally important compounds but a few of them have been validated by scientific criteria and sometimes-medical research does not support their effectiveness by experimental studies. L. lancifolia, which is used as alternative medicine by the people of Chittagong Hill Tracts, Bangladesh, was selected to study its biological activities, as there are very few reports for its biological studies. Litsea lancifolia (Roxb.) Hook. f. which is named as Judijaylla by Chakma tribes belonging to the family Lauraceae is distributed in the forests of southeastern part of Bangladesh. Warm root extract is used frequently by Chakmas to cure diarrhea in Rangamati (Yusuf et al. 2009). A new bis-benzylisoquinoline, lancifoliaine and seven known alkaloids, namely $N$-allyllaurolitsine, reticuline, actinodaphnine, norboldine, pallidine, cassythicine and boldine were isolated from the stem bark of L. lancifolia (Sulaiman et al. 2011).

As part of on going investigation on medicinal plants of Bangladesh (Bulbul et al. 2016, 2017), the crude methanol extract of leaves and its petroleum ether, chloroform and ethyl acetate soluble fractions of $L$. lancifolia were studied for the antioxidant potential in terms of total phenolic content and free radical scavenging, antimicrobial, analgesic, hypoglycemic and CNS depressant activities for the first time and the results of the preliminary investigations are reported.

The plant sample of Litsea lancifolia (DACB-35164) was collected from Chittagong Hill Tract, Bangladesh and was identified by Bangladesh National Herbarium, Dhaka for future reference. The collected plant materials were cleaned, sun-dried and pulverized. The grounded plant material $(800 \mathrm{~g})$ was soaked in methanol at room temperature for 7 days. The extract was filtered through fresh cotton bed and finally with Whatman No. 1 filter paper. The filtrates were concentrated with a rotary evaporator at reduced temperature and pressure. An aliquot $(10 \mathrm{~g})$ of the concentrated methanol extract was fractionated by using the protocol designed by Kupchan

*Author for corresponding: <r.pchem@yahoo.com>. 
and Tsou (1973) and modified version of van Wagenen et al. (1993). In brief, $5 \mathrm{~g}$ of the crude extract was tritrated with $90 \%$ methanol in water. The prepared solution was then fractionated successfully using solvents of increasing polarity, such as petroleum ether, chloroform and ethyl acetate. All the organic soluble fractions were evaporated to dryness by using rotary evaporator at low temperature and kept in airtight containers for further analysis.

Table 1. Kupchan partitionates of Litsea lancifolia leaf.

\begin{tabular}{cc}
\hline Crude extract/fractions* & Leaf $(\mathrm{g})$ \\
\hline ME & 5.00 \\
PESL & 0.87 \\
CSF & 0.50 \\
EASF & 0.45 \\
\hline
\end{tabular}

$* \mathrm{ME}=$ Methanolic crude extract $\mathrm{PESF}=$ Petroleum ether soluble fraction,

$\mathrm{CSF}=$ Chloroform soluble fraction and $\mathrm{EASF}=$ Ethyl acetate soluble fraction.

Gallic acid, Folin-Ciocalteu reagent, DPPH, ascorbic acid, kanamycin, indomethacin, alloxan, metformin hydrochloride, diazepam, acetic acid, tween- 80 and $0.9 \% \mathrm{NaCl}$ saline solution were used in the investigation. The extracts of the plant were dissolved in 1\% Tween- 80 and then in $0.9 \%$ normal saline separately at a concentration of $10 \mathrm{mg} / \mathrm{ml}$ and the required dose was administered according to the weight of each mouse.

Swiss-albino mice of either sex aged 4 - 5 weeks, average weight $20-25 \mathrm{~g}$ were used for the experiment. All the procedures in this study for animal handling were performed according to the protocol of Animal Resources Branch of ICDDR,B. All efforts were made to minimize animal sufferings and to reduce the number of animals used in the experiments. They were kept in standard environmental condition (at $24.0 \pm 1{ }^{\circ} \mathrm{C}$ and $55-65 \%$ relative humidity and $12 \mathrm{hrs}$ light/12 hrs dark cycle) for a week for acclimation after their purchase and fed with rodent food purchased from ICDDR,B and water ad libitum.

The total phenolic content of the extracts was determined with Folin-Ciocalteau reagent by using the method developed by Harbertson and Spayd (2006). Following the method developed by Brand-Williams et al. (1995), the antioxidant activity of the test samples was assessed by evaluating the scavenging activities of the stable1,1-diphenyl-2-picrylhydrazyl (DPPH) free radical by using synthetic antioxidants, ascorbic acid as reference standard. Antimicrobial activity was determined by the disc diffusion method (Bauer et al. 1966). Peripheral analgesic activity was evaluated by formalin-induced paw licking method (Pourmotabbed et al. 2011).

Hypoglycemic activity was evaluated by Sekar et al. (1990) in the present experiment, 20 mice (16 diabetic, 4 normal mice) were used. The mice were divided into five groups each containing four mice as shown below:

Group I: Normal control (Non diabetic) mice were administrated $1 \mathrm{ml}$ of distilled water

Group II: Diabetic control (Untreated group) mice were untreated.

Group III: Diabetic mice were administrated metformin (100 $\mathrm{mg} / \mathrm{kg}$ b.w.) daily using an intragastric tube for 7 days.

Group IV: Diabetic mice were administrated methanolic extract of L. lancifolia (300 mg/kg b.w.) daily for 7 days.

Group V: Diabetic mice were administrated methanolic extract of L. lancifolia $(500 \mathrm{mg} / \mathrm{kg} \mathrm{b.w.)}$ daily for 7 days.

For all bioassays, three replicates of each sample were used for statistical analysis and the values are reported as mean $\pm \mathrm{SD}$. 
The petroleum ether, chloroform and ethyl acetate soluble fractions of the crude methanol extract as well as Kupchan partitionates of L. lancifolia were evaluated for the antioxidant, antimicrobial, peripheral analgesic, hypoglycemic and CNS depressant activities bioassay.

The total phenolic content of the extractives of leaves of $L$. lancifolia was found to range from $15.96 \pm 0.23$ to $79.93 \pm 0.63 \mathrm{mg}$ of GAE/g of extractives, with the highest amount of phenolics $79.93 \pm 0.63$ being observed in the ethyl acetate soluble fraction (Table 2). In the DPPH free radical scavenging assay, the chloroform fraction of leaves of $L$. lancifolia showed maximum free radical scavenging activity having $\mathrm{IC}_{50}$ value of $64.01 \pm 0.30 \mu \mathrm{g} / \mathrm{ml}$ while the standard ascorbic acid showed $\mathrm{IC}_{50}$ value of $51.54 \pm 0.17 \mu \mathrm{g} / \mathrm{ml}$ (Table 2).

Table 2. Total phenolic content and DPPH free radical scavenging activity of $L$. lancifolia.

\begin{tabular}{lcc}
\hline $\begin{array}{l}\text { Plant sample/ } \\
\text { standard }\end{array}$ & $\begin{array}{c}\text { Total phenolic content } \\
(\mathrm{mg} \text { of GAE/gm of } \\
\text { extract) }\end{array}$ & $\begin{array}{c}\text { DPPH free radical } \\
\text { scavenging activity } \\
\left(\mathrm{IC}_{50} \mu \mathrm{g} / \mathrm{ml}\right)\end{array}$ \\
\hline PESF & $15.96 \pm 0.23$ & $65.95 \pm 0.69$ \\
CSF & $33.35 \pm 0.55$ & $64.01 \pm 0.30$ \\
EASF & $79.93 \pm 0.63$ & $75.44 \pm 4.80$ \\
Ascorbic acid & & $51.54 \pm 0.17$ \\
\hline
\end{tabular}

PESF $=$ Petroleum ether soluble fraction, $\mathrm{CSF}=$ Chloroform soluble fraction and EASF $=$ Ethyl acetate soluble fraction.

Table 3. Zones of growth inhibition (mm) showing antimicrobial activity for three fractions of $L$. lancifolia.

\begin{tabular}{lllll}
\hline Microorganisms & PESF & CSF & EASF & $\begin{array}{l}\text { Kanamycin/ } \\
\text { griseofulvin }\end{array}$ \\
\hline Bacillus subtilis & $11.00 \pm 0.82$ & $17.33 \pm 0.47$ & $14.67 \pm 0.47$ & $35.00 \pm 0.82$ \\
B. megaterium & $13.33 \pm 0.47$ & $16.50 \pm 0.41$ & $8.67 \pm 0.47$ & $33.33 \pm 0.47$ \\
B. cereus & $8.17 \pm 0.62$ & $18.33 \pm 0.47$ & $14.17 \pm 0.24$ & $35.33 \pm 1.25$ \\
Escherichia coli & $11.75 \pm 0.75$ & $12.83 \pm 0.85$ & $22.33 \pm 0.47$ & $33.00 \pm 0.82$ \\
Pseudomonas aeruginosa & $23.50 \pm 0.50$ & $9.33 \pm 0.47$ & - & $30.67 \pm 0.47$ \\
Salmonella paratyphi & - & $18.50 \pm 0.41$ & $8.83 \pm 0.85$ & $32.17 \pm 0.24$ \\
Sarcina lutea & - & $10.67 \pm 0.94$ & $8.50 \pm 0.41$ & $33.50 \pm 0.41$ \\
Shigella dysenteriae & $17.50 \pm 1.50$ & $14.33 \pm 0.94$ & - & $33.67 \pm 0.47$ \\
S. boydii & $13.50 \pm 0.50$ & $18.17 \pm 0.24$ & - & $32.67 \pm 0.47$ \\
Staphylococcus aureus & $18.33 \pm 1.25$ & $14.67 \pm 0.47$ & $10.17 \pm 0.24$ & $33.33 \pm 0.47$ \\
Vibrio mimicus & $14.75 \pm 0.25$ & - & $10.67 \pm 0.94$ & $31.83 \pm 0.24$ \\
V. parahemolyticus & - & $9.33 \pm 0.47$ & $11.67 \pm 0.47$ & $32.50 \pm 0.41$ \\
Candida albicans & - & $12.67 \pm 0.94$ & $9.50 \pm 0.41$ & $30.67 \pm 0.47$ \\
Asperagillus niger & - & $9.17 \pm 0.62$ & $10.67 \pm 0.47$ & $31.67 \pm 0.47$ \\
$\begin{array}{l}\text { Sacharomyeces } \\
\text { cereveceae }\end{array}$ & - & $7.33 \pm 0.47$ & - & $30.50 \pm 0.41$ \\
\hline
\end{tabular}

Values for zone of growth inhibition are presented as mean $\pm \mathrm{Sd}$. - Indicates inhibition (disc diameter is 5.0 $\mathrm{mm})$

The result of the investigation for the antibacterial activity of different partitionates of L. lancifolia has been summarized in Table 3. The Petroleum ether soluble fraction (PESF) of $L$. lancifolia showed potent antimicrobial activity against $P$. aeruginosa $(23.50 \mathrm{~mm})$, very good activity against $S$. aureus $(18 \mathrm{~mm})$ and $S$. dysenteriae $(17.50 \mathrm{~mm})$, whereas exhibited mild to 
moderate activity against $B$. subtilis $(11 \mathrm{~mm}), B$. megaterium $(13 \mathrm{~mm})$, E. coli $(11 \mathrm{~mm})$ and $V$. mimicus $(14 \mathrm{~mm})$. The chloroform soluble fraction $(\mathrm{CSF})$ revealed very good activity against B. cereus, S. paratyphi, S. boydii $(18 \mathrm{~mm})$, B. subtilis $(17 \mathrm{~mm})$ and B. megaterium $(16.50 \mathrm{~mm})$. The CSF showed mild to moderate activity $(9$ to $14 \mathrm{~mm}$ ) against $S$. aureus, S. lutea, E. coli, $P$. aeruginosa, V. parahemolyticus, S. dysenteriae, C. albicans, A. niger and S. cereveceae. The ethyl acetate soluble fraction (EASF) demonstrated potent antimicrobial activity against $E$. coli $(22.33 \mathrm{~mm})$ whereas moderate activity against B. subtilis $(14.67 \mathrm{~mm})$ and B. cereus $(14.17 \mathrm{~mm})$.

The leaf extract of $L$. lancifolia showed statistically significant peripheral analgesic activity at both doses of 100 and $200 \mathrm{mg} / \mathrm{kg}$ body weight with writhing inhibition of 69.45 and $77.96 \%$, respectively (Table 4).

Table 4. Peripheral analgesic activity of methanolic crude extract of $L$. lancifolia.

\begin{tabular}{llll}
\hline Group & Drug/ Test sample (Dose) & No. of writhing & \% of inhibition \\
\hline Group I (Control) & Saline water, Tween 80 & $14.75 \pm 3.21$ & - \\
Group II (Standard) & Indomethacin, $10 \mathrm{mg} / \mathrm{kg} \mathrm{b.w.}$ & $3.00 \pm 1.20^{* * *}$ & 79.66 \\
Group III & L. lancifolia $100 \mathrm{mg} / \mathrm{kg} \mathrm{b.w.}$ & $4.50 \pm 3.21^{* *}$ & 69.45 \\
Group IV & L. lancifolia $200 \mathrm{mg} / \mathrm{kg} \mathrm{b.w.}$ & $3.25 \pm 2.075^{* *}$ & 77.96 \\
\hline
\end{tabular}

All values are expressed as mean \pm SEM, $(\mathrm{n}=6)$; One way ANOVA followed by DMRT. ***p $<0.001$, **p $<0.01, * \mathrm{p}<0.05$, significant compared to control.

Table 5. Hypoglycemic Activity of methanolic crude extract of $L$. lancifolia.

\begin{tabular}{lllll}
\hline \multirow{2}{*}{ Groups } & \multicolumn{3}{c}{ Blood glucose level } \\
\cline { 2 - 5 } & 1st day & 3rd day & 5 th day & 7th day \\
\hline Control (non-diabetic) & $5.20 \pm 0.17$ & $5.01 \pm 0.13$ & $5.50 \pm 0.35$ & $4.87 \pm 0.26$ \\
Control (diabetic) & $10.65 \pm 0.22$ & $10.16 \pm 0.49$ & $12.54 \pm 0.32$ & $11.93 \pm 0.51$ \\
STD (Metformin HCl) 50 & $12.46 \pm 0.67$ & $5.53 \pm 0.27^{* *}$ & $4.46 \pm 0.14^{* *}$ & $4.26 \pm 0.32^{* *}$ \\
mg/kg b.w./day & $12.85 \pm 1.63$ & $10.8 \pm 1.2$ & $8.15 \pm 0.77$ & $7.6 \pm 0.44$ \\
MELL 300 mg/kg b.w./day & $11.5 \pm 0.63$ & $9.3 \pm 0.94$ & $7.7 \pm 0.54$ & $7.0 \pm 0.75^{*}$ \\
MELL 500 mg/kg b.w./day & 11.04 &
\end{tabular}

All values are expressed as mean \pm SEM, $(n=6)$; ANOVA followed by DMRT. ***p $<0.001$, **p $<0.01$, $* p<0.05$ significant compared to control.

Table 6. CNS depressant activity of methanol extract of $L$. lancifolia leaves.

\begin{tabular}{|c|c|c|c|c|c|c|}
\hline \multirow{2}{*}{ Treatment } & \multirow{2}{*}{ Doses } & \multicolumn{5}{|c|}{ Number of movements } \\
\hline & & $0 \mathrm{~min}$ & $30 \mathrm{~min}$ & $60 \mathrm{~min}$ & $90 \mathrm{~min}$ & $120 \mathrm{~min}$ \\
\hline $\begin{array}{l}1 \% \text { Tween } 80 \\
\text { in Saline water } \\
\text { (Control) }\end{array}$ & $\begin{array}{l}10 \mathrm{ml} / \mathrm{kg} \\
\text { b.w./day }\end{array}$ & $13.50 \pm 1.19$ & $14.00 \pm 1.29$ & $14.25 \pm 0.85$ & $14.00 \pm 1.08$ & $13.50 \pm 0.29$ \\
\hline $\begin{array}{l}\text { Diazepam } \\
\text { (Standard) }\end{array}$ & $\begin{array}{l}1 \mathrm{mg} / \mathrm{kg} \\
\text { b.w./day }\end{array}$ & $10.75 \pm 0.48$ & $6.75 \pm 0.25^{*}$ & $4.00 \pm 0.48^{*}$ & $2.75 \pm 0.48$ & $1.50 \pm 0.29^{*}$ \\
\hline PESF & $\begin{array}{l}500 \mathrm{mg} / \mathrm{kg} \\
\text { b.w./day }\end{array}$ & $5.75 \pm 0.48 * * *$ & $3.75 \pm 0.48 * * *$ & $3.00 \pm 0.41 * * *$ & $1.75 \pm 0.48 * * *$ & $1.75 \pm 0.25 * * *$ \\
\hline CSF & $\begin{array}{l}500 \mathrm{mg} / \mathrm{kg} \\
\text { b.w./day }\end{array}$ & $6.50 \pm .65^{* * *}$ & $0.50 \pm 0.41 * * *$ & $3.50 \pm 0.29 * * *$ & $2.00 \pm 0.41 * * *$ & $1.50 \pm 0.29 * * *$ \\
\hline EASF & $\begin{array}{l}500 \mathrm{mg} / \mathrm{kg} \\
\text { b.w./day }\end{array}$ & $6.00 \pm 0.41 * * *$ & $4.00 \pm 0.58 * * *$ & $3.50 \pm 0.29 * * *$ & $1.750 \pm 0.48 * * *$ & $1.75 \pm 0.25 * * *$ \\
\hline
\end{tabular}


The effects of methanol extract of L. lancifolia leaves on blood glucose level in alloxan induced diabetic rats are shown in Table 5 which indicated that the blood glucose level significantly decreased $(\mathrm{p}<0.05)$ on 7 th day of treatment after administration of $500 \mathrm{mg} / \mathrm{kg} / \mathrm{day}$ of the extract.

In this test, the extract showed a decrease in locomotion in the test animals. The number of crossing hole from one chamber to another by mice of the control group remained almost steady from 0 to $120 \mathrm{~min}$ (Table 6). But the three different fractionates at $500 \mathrm{mg} / \mathrm{kg}$ dose showed significant and gradual decrease of movement from 0 to $120 \mathrm{~min}$. This result of the study showed to have CNS depressant potential in L. lancifolia.

\section{Reference}

Bauer AW, Kirby WMM, Sheriss JC and Turck M 1966. Antibiotic susceptibility testing by standardised single method. Am. J. Clin. Pathol. 45: 493-496.

Brand-Williams W, Cuvelier ME and Berset C 1995. Use of free radical method to evaluate antioxidant activity. Lebensm. Wiss. Technol. 28: 25-30.

Bulbul IJ, Khan MF, and Rashid MA 2016. Analgesic and central nervous system depressant activities of methanol extract of Ziziphus rugosa Lam. Leaves. Afr. J. Pharm. Pharmacol. 10: 849-853.

Bulbul IJ, Fashiuddin SB, Haque MR, Sultan MZ and Rashid MA 2017. Anti-nociceptive and antiinflammatory Activities of Crotalaria pallida Aiton (Fam: Fabaceae) leaves. Bangladesh Pharm. J. 20: $165-171$.

Harbertson J and Spayd S 2006. Measuring phenolics in the winery. Am. J. Enol. Vitic. 57: 280-288.

Kupchan SM and Tsou G 1973. Tumor inhibitors. LXXXI, structure and partial synthesis of fabacein. J. Org. Chem. 38: 178.

Pourmotabbed A, Farshchi A, Ghiasi G and Khatabi PM 2001. Analgesic and anti-inflammatory activity of Teucrium chamaedrys leaves aqueous extract in male rats. Soc. Sci. Med. 34: 735-746.

Sekar N, Kanthasamy A, William S, Subramanian S and Govindasamy S 1990. Insulinic actions of vanadate in diabetic rats. Pharmacol. Res. 22: 207-217.

Sulaiman SN, Mukhtar MR, Hadi AHA, Awang K, Hazni H, Zahari A, Litaudon M, Zaima K, and Morita H 2011. Lancifoliaine, a new cisbenzylisoquinoline from the Bark of Litsea lancifolia, Molecules 16: 3119-3127.

Van Wagenen BC, Larsen R, Cardellina JH, Randazzo D, Lidert ZC and Swithenbank C 1993. Ulosantoin, a potent insecticide from the sponge Ulosa ruetzleri. J. Org. Chem. 58: 335-337.

Yusuf M, Chowdhury JU, Wahab MA and Begum J 1994. Medicinal plants of Bangladesh. Dhaka: Bangladesh Centre for Scientific and Industrial Research (BCSIR). pp.1-340.

Yusuf M, Begum J, Hoque MN and Chowdhury JU 2009. Medicinal Plants of Bangladesh (revised and enlarged). Bangladesh Council of Scientific and Industrial Research Laboratories, Chittagong, Bangladesh. p. 794. 